\title{
CONSTRUCTION AND AGRICULTURAL DRAINAGE PARAMETER OPTIMIZATION CONSIDERING ECONOMIC AND ENVIRONMENTAL REQUIREMENTS
}

\author{
Pyotr Kovalenko $^{1}$, Anatoliy Rokochinskiy ${ }^{2}$, Yury Mazhayskiy ${ }^{3}$, Pavlo Volk ${ }^{2}$, \\ Liubov Volk ${ }^{2}$, Olga Chernikova ${ }^{4}$ \\ ${ }^{1}$ Institute of Water Problems and Land Reclamation of NAAS of Ukraine, Ukraine; \\ ${ }^{2}$ National University of Water and Environmental Engineering, Russia; \\ ${ }^{3}$ All-Russian Research Institute of Hydrotechnics and Melioration named \\ after A.N. Kostyakova, Russia; ${ }^{4}$ Academy of Law Management of the Federal \\ Penal Service of Russia, Russia \\ pitkovalenko@gmail.com, a.m.rokochinskiy@nuwm.edu.ua, director@mntc.pro, \\ p.p.volk@nuwm.edu.ua, 1.r.volk@ukr.net, chernikova_olga@inbox.ru
}

\begin{abstract}
Drainage on drained lands is the main regulator of water-air and general natural reclamation regime. Currently, the most promising economic and mathematical method is considered, which combines the advantages of hydro-mechanical and empirical methods and is based on the implementation of a set of forecast and optimization calculations. However, in the conditions of transition to market relations, this method, as it is implemented, does not allow to determine the optimal drainage parameters differentially with respect to different levels of crop yield in compliance with modern economic and environmental requirements in the changeable natural-agro-reclamation conditions of the real object, so it needs further improvement. In this regard, the principles of construction and implementation of a comprehensive model for optimizing agricultural drainage parameters are developed, taking into account the climatological strategy of object management, based on the implementation of interrelated structural and technological, forecast-simulation and optimization blocks of models. This makes it possible to determine economically feasible and environmentally acceptable design solutions based on the relevant criteria. As economic criteria and conditions of the optimization deal with the minimization of costs subject to climatic risk, and environmental component - condition in the form of a matching constraint values of the module of drainage flow within the system ecologically acceptable value. The scientific principles of construction and implementation of structural-technological, forecast-simulation and optimization blocks of models based on changeable natural-agro-meliorative conditions of a real object have been developed, which allow obtaining differentiated values of yield corresponding to the considered variants of drainage parameters, as well as evaluating the technological and environmental efficiency of its operation within the project period.
\end{abstract}

Keywords: improvement, method, optimization, parameters, agricultural drainage.

\section{Introduction}

The development of large-scale reclamation associated with considerable investments, a notable economy of any country, but the resulting effect of this is at best $60 \ldots 70 \%$ of the project. One of the main reasons is the imperfection of existing methods of the drainage system design and calculation [1].

In addition, together with the need to improve the economic efficiency of drainage reclamation today is an extremely acute problem of validity of reclamation activities on environmental requirements $[2 ; 3]$.

Construction projects and reconstruction of reclamation facilities should provide impact of reclamation activities on all aspects of its implementation. So, it needs to develop new approaches and advanced methods of study, especially the construction and agricultural drainage parameters as the defining element of the regulatory drainage system [3].

The theoretical basis of the science of soil drainage works were laid by H. Darsi, J. Dupuis, J. Boussinesq and others. Later their developed theoretical foundations received further development to calculate the basic parameters of agricultural drainage, which developed both in our country and abroad: A.M. Kostyakovym, S.F. Aver'yanovym, V.V. Vedernykovym, V.V. Shestakovym, O.Y. Oliynykom, M.H. Pyvovarom, V.L. Polyakovym, O.I. Ivytskym, O.I. Murashko, V.T. Klymkovym, V.A. Ionatom, A.M. Yanholem, S.A. Brusylivsky, O.I. Holovanovym, V.Y. Shapranom and other authors, as well as foreign scientists Hooghoudt, Ernst, Kirkham, Schilfgoarde, R. Ylover, K. Engelsmann, Ramanauskas, G. Kunze. 
At various stages of reclamation science are known scientific schools by two main methods of calculating the parameters of agricultural drainage, the hydromechanics method based on theoretical principles of water movement in natural and technical systems and empirical, based mainly on statistical data processing numerous field studies. Each method has its advantages and disadvantages.

It should be noted that the hydromechanics method of determining the distance between the drains is the most reasonable in theory, but it does not take into account economic, environmental, and some regime-technological aspects of drainage.

Moreover, most obtained through this method formulas do not account for the presence of the initial pressure gradient which causes water movement [4]. Excluding this condition error of distance between the drains can range from $3 \%$ to $40 \%$, depending on the length of the dehydration period.

A major shortcoming of the hydromechanics formula is also neglect of drainage runoff formation conditions in the phase of raising the level of groundwater that is more intense compared with the phase of recession [4]. However, this method allows to make a qualitative analysis of hydrological factor action drainage, hydrodynamic processes, occurring in soils for the entire set of settlement patterns in real environmental conditions, drainage features in general and filtering element. Hydromechanics formulas are also of great importance when summarizing data from field research of drainage. The main drawback of hydro-mechanical calculations is that the obtained parameters of drainage are not justified from an economic and environmental point of view. That is, they do not include the costs of construction and operation of drainage and its impact on the environment.

In the practice of designing drainage systems widely an empirical method is used, whereby the distance between the drains set depending on one or more factors affecting the intensity of drainage (particle-size distribution, physical and chemical soil constitution, rainfall intensity, soil permeability etc.). It is based on the assumption that if the heavier soils and lower filtration properties, the smaller should be the distance between the drains (Mitterlih, Shkinkys C.N., Pysarkov V.P., A. Dumblyauskas, Kubyshkin V.P., Sapsay G.I. and others).

In turn, in addition to costs of its development and implementation, it has a very limited scope of application, the terms define zonal location of the object.

\section{Materials and methods}

So, today the most promising is considered the economic-mathematical method that combines the advantages of hydro and empirical methods and is based on the realization of complex forecasting, optimization calculations (K.T. Hommik, I.S. Rabochev, I.V. Mina, Y.M. Nikolskyy, L.A. Downey, J. Doorenbos, A.H. Kassam, M.O. Lazarchyk, A.P. Lihacevych, P.I. Kovalchuk).

However, in the transition to market economy this method in the form as it is implemented will not allow differentiated determination of the optimum parameters of drainage on various performance levels produced crops in compliance with the current economic and environmental requirements in varying reclamation (soil, hydrogeological, climatic, agronomic, economic and environmental) conditions of a real object, and therefore needs further improvement.

The research methods are based on the application of the systems theory with the basics of the systems approach, systems analysis, and modeling. For this purpose, appropriate software and information were used to develop approaches to substantiate technical and technological solutions for water regulation of drained lands. This approach is used in science, technology and industry and is called computer-aided design or BIM-technology.

Based on them, we have improved the technology of designing water management and reclamation objects. That is, it is based on a multivariate assessment of technological, technical, economic, environmental efficiency of design solutions for the appropriate set of optimization and forecasting and simulation models, methodological and informational support for their implementation [4].

\section{Results and discussion}

The Ukrainian and world experience of creation and functioning of drainage systems, and also the results of our theoretical and experimental researches were generalized. We have developed 
approaches to optimize the parameters of agricultural drainage taking into account economic and environmental conditions.

The essence of improving the optimization method is to develop an integrated model parameter optimization drainage, which, unlike the current economic and mathematical methods, taking into account both economic and environmental aspects of its work and making it possible to identify economically viable and environmentally acceptable design choices (DC) for its arrangement [9].

$$
\left\{\begin{array}{l}
Z P_{0}=\min _{\{i\}} \sum_{n=1}^{n_{p}} Z P_{i p} \cdot \alpha_{p}, i=\overline{1, n_{i}} ; \\
q_{0}=\min _{\{i\}} \sum_{n=1}^{n_{p}}\left|q_{s}-\hat{q}_{e c o l}\right| \cdot \alpha_{p}, i=\overline{1, n_{i}},
\end{array}\right.
$$

where $Z P_{0}-$ optimum value for the criterion $i$-m option of the sum total $\{i\}, i=\overline{1, n_{i}} \mathrm{UAH} \cdot \mathrm{ha}^{-1}$; $\alpha_{p}-$ known (defined or set) number of replications of particles will probably become typical meteorological regimes in the settlement during the growing season of the input set $\{p\}, p=\overline{1, n_{p}}$ within the designed lifetime of the object, $\sum_{p=1}^{n_{p}} \alpha_{p}=1$;

$q_{0}$ - optimum estimated value of the drainage module for the i-version of DC, $1 \cdot(\mathrm{s} \cdot \mathrm{ha})^{-1}$; $q_{s}$ - average weighted value of the drainage module within the system and the project lifetime of the object under for the i-th DC, $1 \cdot(\mathrm{s} \cdot \mathrm{ha})^{-1}$;

$\hat{q}_{\text {ecol }}$ - limit values of the drainage flow module that meets the environmental efficiency of the drainage level in the studied conditions, $1 \cdot(\mathrm{s} \cdot \mathrm{ha})^{-1}$;

$i$ - variants of DC of the sum total $\{i\}, i=\overline{1, n_{i}}$ for the type, design and drainage parameters.

The general economic criterion of optimization is the indicator of the reduced expenses $Z$, taking into account the weather and climate risk $R_{i}$, which is reduced to the comparative form $Z P$ by volume (value) $V$ of the received products according to the corresponding variants of DC $\{i\}$.

$$
Z P_{i}=\frac{\left(C_{i}^{c 2}+C_{i}^{M}+A_{i}+E_{H} \cdot K_{i}+R_{i}\right)}{V_{i}}, i=\overline{1, n_{i}},
$$

where $C_{i}^{c 2}$-agricultural costs for growing crops for the i-variant of DC UAH $\cdot \mathrm{ha}^{-1}$;

$C_{i}^{n}$ - reclamation costs or operating costs for the i-variant of DC UAH $\cdot \mathrm{ha}^{-1}$;

$A_{i}$ - depreciation costs for the $i$-variant of DC UAH $\cdot$ ha $^{-1}$;

$E_{n}$ - normative coefficient of economic efficiency of capital investments on the drainage excavation $K_{i}$ for the $i$-variant of DC UAH $\cdot \mathrm{ha}^{-1}$.

The weather and climate risk is defined $[9 ; 15]$

$$
R_{i}=\sqrt{\left(V_{i}-\hat{V}_{i}\right)^{2}},
$$

where $V_{i}$-value of product cost of the actual yield obtained for the i-variant of DC UAH $\cdot$ ha $^{-1}$;

$\hat{V}_{i}$ - value of product cost for the potential yield on the object, $\mathrm{UAH} \cdot \mathrm{ha}^{-1}$.

The work of drainage in the dehydration period leads to increased wash water treatment reducing soil fertility through leaching of nutrients and abuse of the soil structure. The criterion of the ecological optimal of DC on the parameters of drainage may be a deviation of the weighted mean of the drainage modulus within the system and project term operation of the object $q_{s}$ the limit value of the drainage modulus corresponding $\hat{q}_{\text {ecol }}$ to the level of environmental efficiency of the investigated drainage object.

All components of the complex optimization model, such as technical and economic indicators of the economic and mathematical model (investment, product cost, current agricultural, amortization and reclamation expenses, etc.), as well the environmental indicator (criterion) of the water overall natural reclamation land dehydration period are defined of the parameters adopted for agricultural drainage. They are variable and depend on many factors, foremost of which are structural and technical logical, climatic, soil reclamation, agrotechnical and other terms of the object. 
They can be schematically represented as baseline data for formulating and solving optimization problems through appropriate aggregate multiple variables:

- constructive and technological multiple variables: types of drainage material for manufacturing of the sum total $\{b\}, b=\overline{1, n_{b}}$; drainage designs for different diameters pipes of the sum total $\{d\}, d=\overline{1, n_{d}}$; filter designs of the drainage of the sum total $\{\varphi\}, \varphi=\overline{1, n_{\varphi}}$; design scheme of drainage on existing soil-reclamation differences of the sum total $\left\{m_{g}\right\}, m_{g}=\overline{1, n_{m_{g}}}$;

- predictive and simulated multiple variables: weather station within the systems of the sum total $\{\omega\}, \omega=\overline{1, n_{\omega}}$; estimated periods of vegetation under conditions of heat and moisture provision of the sum total $\{p\}, p=\overline{1, n_{p}}$; types of drained soils of the sum total $\{g\}, g=\overline{1, n_{g}}$; cultivated crops of the project crop rotation of the sum total $\{k\}, k=\overline{1, n_{k}}$; ways of water regulation of the sum total $\{s\}, s=\overline{1, n_{s}}$ (in this case, $s=1-$ dehydration).

The economic component of the complex model of optimization of drainage parameters can be realized through the connection of the type of drainage modulus $(q) \Leftrightarrow$ the distance between the drains $(B) \Leftrightarrow$ the output yield $(Y)$.

If entered the necessary notation, the functional connection between the components of the subsystem in the general case

$$
Y_{i}=f_{1}\left(f_{2}\left(B_{i}\right)\right), i=\overline{1, n_{i}} .
$$

Function (4) in our case acts as the basis of the "production function" for the implementation of the economic component of the optimization model (1), but it has no direct solution, its elements and the functional relationship between them have examples of implementation at the scientific and production level.

The function between drainage parameters $\left(B_{i}\right)$ and water control technologies $\left(q_{i}\right)$ is represented as an inverse function

$$
B_{i}=f_{1}^{\prime}\left(q_{i}\right) .
$$

To implement the function (5), we use the common formula for homogeneous and layered soils (DBN B.2.4-1-99, the development of O.Y. Oliynyk and A.I. Murashko [5]).

This formula takes into account the design features of horizontal drainage and is implemented for the case of shallow aquiclude, when $m_{D} \leq E / 4$, as

$$
B_{i}=4\left(\sqrt{L_{f_{i}}^{2}+\frac{H T}{2 q_{i}}}-L_{f_{i}}\right), i=\overline{1, n_{i}} ;
$$

where $m_{D}$-distance from the axis of drains to aquiclude, $\mathrm{m}$;

$B$ - distance between drains, $\mathrm{m}$;

$L_{f}-$ general filtration resistance according to the degree and nature of the formation of the geological bed;

$H$ - design head, m;

$T$ - water penetration capacity of the geological bed $\mathrm{m}^{2} \cdot \mathrm{day}^{-1}$;

$q$ - intensity of infiltration supply, $\mathrm{m} \cdot \mathrm{day}^{-1}$.

The effectiveness of its application is confirmed by other researchers and practice in the area of drainage and irrigation reclamation.

In the existing calculation methods, the drainage parameters are determined on the basis of the unit design values of the drainage modulus, with only technological requirements for its work on reducing the level of groundwater and removing excess water from the active root zone of the drained soil during the spring (main) period.

Proceeding from the modern technological, economic and environmental requirements for drainage work, in the implementation of a comprehensive model of optimization (1) we are proposed to determine the set of estimated values of the drainage modulus, taking into account different levels 
of productivity, value and profitability of cultivated crops in the conditions of a real object by the corresponding set variants of DC [10].

Realization of the function between the parameters of the effect $\left(Y_{i}\right)$ and the water control technologies $\left(q_{i}\right)$ :

$$
Y_{i}=f_{2}\left(q_{i}\right) .
$$

The main settlement period of drainage is the spring period. Therefore, the effect of his work on the formation of the crop of cultivated crops [8] can be determined by the relationship between the effect parameters $\left(Y_{i}\right)$ and the sum of positive average daily air temperatures $\left({ }^{\circ} \mathrm{C}\right)$ accumulated after the date of the optimal period of sowing or restoration of the growing of culture $\left(\sum T_{k}{ }^{B}\right)$ as parameters of the corresponding natural regeneration regime

$$
Y_{i}=f_{2}\left(\sum T_{k}^{6}\right) .
$$

The relationship between different levels of efficiency of the drainage of the sum total $\left\{q_{r}\right\}$, $r=\overline{1, n_{r}}$ ( $r=1$ - environment, $r=2-$ technology, $r=3$ - economic) in the spring calculation period and the levels of productivity (profitability and value) of cultivated crops $U_{k}^{r}=f\left(Y_{k}^{r}\right),\left(U_{k}^{(1)}-\right.$ low $U_{k}^{(2)}$ - average, $U_{k}^{(3)}$ - high) with the corresponding values of the maximum deviation of the average daily air temperatures accumulated from the date of the optimal period of sowing or the restoration of vegetation $\sum \hat{T}_{k}^{B}$ in the zone of their biological optimum

$$
q_{k}^{r}=f_{2}^{\prime}\left(U_{k}^{r}, \sum \hat{T}_{k r}^{B}\right) .
$$

Values $\sum \hat{T}_{k r}{ }^{6}$ are defined as the maximum values of the deviation of the service life or the reestablishment of the vegetation (degree day) of the cultivated crops and the reduction of their yield by the coefficient $k_{3}$ described by the empirical dependence [10]

$$
k_{3}=\frac{1-\left(\lambda_{k} \cdot \sum \hat{T}_{k}^{b}\right)^{2}}{1+\left(\lambda_{k} \cdot \sum \hat{T}_{k}^{b}\right)^{2}},
$$

where $\lambda_{k}$-empirical coefficient.

Proceeding from the general statement of the optimization problem concerning the parameters of drainage, the main requirement for the function of communication between the parameters of the effect (the crop) and the drainage modulus is the need to determine the variable value of the optimum relative to the appropriate level of efficiency of its operation.

Therefore, in the general case, we propose an appropriate function $k_{d i}=f_{2}\left(q_{i}\right)$ that is implemented as a family of corresponding normalized curves in the form of composite functions with a variable character determining the point of "optimal" (given) productivity of the cultivated crop of the project crop rotation $k_{d}=1$ relative to the corresponding values of the drainage modulus parameters at different levels of efficiency of drainage work $\left\{q_{r}\right\}, r=\overline{1, n_{r}}[10 ; 11]$

$$
\begin{gathered}
k_{d}=\left\{\begin{array}{c}
0,49-0,385 \operatorname{arctg}\left(3,28-B_{q}\right), 0 \leq q \leq q_{r} ; \\
0,49+0,385 \operatorname{arct} q\left(3,28-D_{q}\right), q_{r} \leq q \leq 0,
\end{array}\right. \\
B_{q}=7,3 / q_{r} ; D_{q}=7,3 / q_{r} .
\end{gathered}
$$

Thus, based on the results of the implementation of the constructive-technological and forecastsimulation models, the plural values of the drainage modulus according to the variants of the DC of the sum total $\left\{q_{r p i}\right\}, q_{r p i}=\overline{1, n_{q_{p i}}}, r=\overline{1, n_{r}}, p=\overline{1, n_{p}}, i=\overline{1, n_{i}}$ and the corresponding distances between the drains of the sum total $\left\{B_{r p i}\right\}, B_{r p i}=\overline{1, n_{B_{r i}}}, \quad r=\overline{1, n_{r}}, p=\overline{1, n_{p}}, i=\overline{1, n_{i}}$ corresponding to the differentiated yield value are determined of the sum total $\left\{Y_{r p i}\right\}, Y_{r p i}=\overline{1, n_{Y_{r i}}}, \quad r=\overline{1, n_{r}}, \quad p=\overline{1, n_{p}}$, $i=\overline{1, n_{i}}$.

Since the proposed complex model of optimization of design and drainage parameters includes heterogeneous indicators of economic and ecological efficiency, therefore, its practical realization is 
reduced to the definition of economically optimal and environmentally acceptable (expedient) of the DC.

The economic component of the complex optimization model (1) is determined in the general case by the four-level $\left(v=\overline{1, n_{v}}\right)\left(n_{v}=4\right)$ hierarchical structure of the implementation of optimization calculations:

$$
Z P_{0_{v}}=\min _{\{i\}} \sum_{m_{g}=1}^{n_{m_{g}}} \sum_{g_{m}=1}^{n_{g_{m}}} \sum_{k=1}^{n_{k}}\left(\sum_{p=1}^{n_{p}} Z P_{i p k g_{m} m_{g}} \cdot \alpha_{p}\right) \cdot f_{k} \cdot f_{g_{m}} \cdot f_{m_{g}, i=\overline{1, n_{i}}},
$$

where $Z P_{0 v}-$ optimal value of the criterion for each level $v=\overline{1, n_{v}}$ of the hierarchy of the model implementation, respectively at the level of crops of the proposed crop rotation $(v=1)$, soil $(v=2)$, soil-reclamation differences $(v=3)$ and the system as a whole $\left(n_{v}=4\right)$, $\mathrm{UAH} \cdot \mathrm{ha}^{-1}$;

$Z P_{\text {ikpgmg }}$ - value of the optimization criterion for the relevant variants of the DC concerning multiple variables of the natural land reclamation conditions of the object under study, $\mathrm{UAH} \cdot \mathrm{ha}^{-1} ; \quad f_{k}, f_{g}, f_{m g}-$ share distribution of crop rotation design, soil conditions, soil-reclamation differences within the object.

From the results of the implementation of the model (13), we obtain the optimal values of the optimization criterion for each level of the hierarchy $Z P_{0 v}, v=\overline{1, n_{v}}$ in the studied conditions.

Consequently, at the level of the system as a whole, optimal of the DC relative to the parameters of drainage

$$
i_{0}=\left\{Z P_{0}, b_{0}, d_{0}, \varphi_{0}, q_{0}, B_{0}\right\}
$$

The ecological acceptability for a certain economically optimal of the DC on the design and parameters of drainage at the system level is achieved provided

$$
q_{s} \rightarrow \hat{q}_{\text {ecol }},
$$

where $q_{s}$-average value of the drainage modulus within the system and the designed lifetime of the object

$$
q_{s}=\sum_{g=1}^{n_{g}} \sum_{k=1}^{n_{k}}\left[\sum_{p=1}^{n_{p}}\left(\sum_{\tau=1}^{n_{\tau}} q_{k g p \tau} / n_{p \tau}\right) \cdot \alpha_{p}\right] \cdot f_{k} \cdot f_{g}
$$

where $q_{k g p \tau}-$ average decade values of the drainage modulus at the estimated time intervals (decade) of the sum total $\{\tau\}, \tau=\overline{1, n_{\tau}}$, under such variables of the studied object $p=\overline{1, n_{p}}, k=\overline{1, n_{k}}, g=\overline{1, n_{g}}$;

$\hat{q}_{\text {ecol }}$ - average weighted limit value of the drainage modulus corresponding to the ecological level of drainage efficiency within the system

$$
\hat{q}_{\text {ecol }}=\sum_{g=1}^{n_{g}} \sum_{k=1}^{n_{k}}\left(\sum_{p=1}^{n_{p}} \hat{q}_{\text {ecol } k g p} \cdot \alpha_{p}\right) \cdot f_{k} \cdot f_{g},
$$

where $\hat{q}_{\text {ecolkgp }}$ - value of the drainage modulus, when $r$ meets the ecological level of drainage efficiency for the variable conditions of the object under study $p=\overline{1, n_{p}}, k=\overline{1, n_{k}}, g=\overline{1, n_{g}}$.

The determination of the mode-technological, economic and environmental components of the complex optimization model is based on the implementation of forecast-simulation models for determining the yield of drained lands, the long-term predictive assessment of the climatic conditions of the terrain and the water regime, and the technologies of water regeneration of drained lands $[12 ; 13]$.

The principles of construction and realization of the complex model of optimization of the design and drainage parameters, taking into account the multiple variables of the natural land reclamation conditions of the real object, their influence on the crop of cultivated crops and the created economic 
and ecological effect, are based on the interconnected structural and technological simulation and optimization blocks of the models.

Thus, in contrast to traditional hydromechanical, empirical optimization methods and models, the implementation of a comprehensive optimization model (1) makes it possible to determine differentiated optimal drainage parameters. These parameters will be determined for different levels of productivity of cultivated crops, taking into account economic and environmental requirements in the changing natural agro-ameliorative conditions of the real object.

As an example of application of the optimization approach to study design options and agricultural drainage, we have reviewed the lands of FG "Ranok" Rokytne district of Rivne region.

The experimental plot is with a total area of 410 hectares. The soils in the site are sod-medium podzolic gley sand on the sands with $(g=1)$ a coefficient of filtration $\left(k_{\phi}=1.2 \mathrm{~m} \cdot\right.$ day $\left.^{-1}\right)$ and fraction $\left(f_{g m}=0.1\right)$, sod-gleyed $(g=2)$ sabulous $\left(k_{\phi}=1.0 \mathrm{~m} \cdot\right.$ day $\left.^{-1}, f_{g m}=0.3\right)$ and medium-high peat-bogs $(g=3)$, $\left(k_{\phi}=0.4 \mathrm{~m} \cdot \mathrm{day}^{-1}, f_{g m}=0.6\right)$. At the reconstruction site, a plastic drainage with a round perforation and a sand-gravel bearing with a diameter of $63 \mathrm{~mm}$ is inserted. Crop rotation on the array represented by the following crops - oat yield is $\left(Y=36 \mathrm{~kg} \cdot \mathrm{ha}^{-1}\right)$ and fraction $\left(f_{k}=0.12\right)$, perennial herbs for hay $\left(Y=42 \mathrm{~kg} \cdot \mathrm{ha}^{-1}\right)\left(f_{k}=0.25\right)$, winter wheat $\left(Y=30 \mathrm{~kg} \cdot \mathrm{ha}^{-1}\right),\left(f_{k}=0.12\right)$, corn for silage $\left(Y=320 \mathrm{~kg} \cdot \mathrm{ha}^{-1}\right)$, $\left(f_{k}=0.13\right)$ and potatoes $\left(Y=210 \mathrm{~kg} \cdot \mathrm{ha}^{-1}\right),\left(f_{k}=0.13\right)$.

The generalized results of optimization calculations concerning the hierarchical levels of their culture-soil-soil-reclamation difference-system for the investigated object by the complex optimization method are given in Table. 1

Table 1

Generalized results of calculation of drainage parameters and construction of the drainages by the complex optimization method in the variable natural agromelioration conditions of the investigated object

\begin{tabular}{|c|c|c|c|c|c|c|c|c|c|}
\hline \multirow[t]{2}{*}{$\begin{array}{l}\text { Soil type, } \\
\qquad g_{m}\end{array}$} & \multirow[t]{2}{*}{ Crop, $k$} & \multicolumn{2}{|c|}{$\begin{array}{l}\text { At level of } \\
\text { crop, } v=1\end{array}$} & \multicolumn{2}{|c|}{$\begin{array}{c}\text { On level of } \\
\text { soil, } v=2\end{array}$} & \multicolumn{2}{|c|}{$\begin{array}{l}\text { At level of soil- } \\
\text { reclamation } \\
\text { difference, } v=3\end{array}$} & \multicolumn{2}{|c|}{$\begin{array}{c}\text { At level of } \\
\text { the level, } \\
\qquad v=4\end{array}$} \\
\hline & & $\left(q_{0}\right)$ & $\left(\boldsymbol{B}_{0}\right)$ & $\left(q_{0}\right)$ & $\left(B_{0}\right)$ & $\left(q_{0}\right)$ & $\left(\boldsymbol{B}_{0}\right)$ & $\left(q_{0}\right)$ & $\left(\boldsymbol{B}_{\mathbf{0}}\right)$ \\
\hline \multirow{5}{*}{$\begin{array}{l}\text { Soddy- } \\
\text { medium- } \\
\text { podzolic } \\
\text { gley sandy } \\
g=1\end{array}$} & Oat & 0.4 & 38.00 & & & & & & \\
\hline & $\begin{array}{l}\text { Winter } \\
\text { wheat }\end{array}$ & 0.5 & 32.00 & & & & & & \\
\hline & $\begin{array}{c}\text { Perennial } \\
\text { grasses }\end{array}$ & 0.6 & 30.00 & & & & & & \\
\hline & $\begin{array}{c}\text { Corn for the } \\
\text { silage }\end{array}$ & 0.5 & 32.00 & & & & & & \\
\hline & Potato & 0.85 & 26.00 & 0.85 & 26.00 & 0.85 & 26.00 & & \\
\hline \multirow{5}{*}{$\begin{array}{l}\text { Soddy- } \\
\text { gley sandy } \\
\text { loam } \\
g=2\end{array}$} & Oat & 0.45 & 36.00 & & & & & & \\
\hline & $\begin{array}{l}\text { Winter } \\
\text { wheat }\end{array}$ & 0.55 & 30.00 & & & & & & \\
\hline & $\begin{array}{c}\text { Perennial } \\
\text { grasses }\end{array}$ & 0.5 & 28.00 & & & & & & \\
\hline & $\begin{array}{l}\text { Corn for the } \\
\text { silage }\end{array}$ & 0.5 & 28.00 & & & & & & \\
\hline & Potato & 0.8 & 24.00 & 0.8 & 24.00 & 0.8 & 24.00 & & \\
\hline \multirow{5}{*}{$\begin{array}{l}\text { Medium- } \\
\text { high peat- } \\
\text { bogs } \\
g=3\end{array}$} & Oat & 0.4 & 30.00 & & & & & & \\
\hline & $\begin{array}{l}\text { Winter } \\
\text { wheat }\end{array}$ & 0.45 & 26.00 & & & & & & \\
\hline & $\begin{array}{c}\text { Perennial } \\
\text { grasses }\end{array}$ & 0.55 & 22.00 & & & & & & \\
\hline & $\begin{array}{c}\text { Corn for the } \\
\text { silage }\end{array}$ & 0.5 & 24.00 & & & & & & \\
\hline & Oat & 0.6 & 20.00 & 0.6 & 20.00 & 0.6 & 20.00 & 0.6 & 20.00 \\
\hline
\end{tabular}


Note: in this case, under the conditions of the object under study, the results of the optimization calculations coincide at the hierarchical levels (the soil and the soil-reclamation difference).

The obtained results of the calculation for different levels of crop yields show that for certain conditions the optimal distances between the drains at the lowest level of the crop-soil hierarchy change by $g=1$ from $26 \mathrm{~m}$ for potatoes with the economic optimization criterion $Z P_{0}=0.91$ to $38 \mathrm{~m}$, for grain from $Z P_{0}=1.04$ with the change of the calculated drainage modulus from $q_{\text {ekol }}=0.4$ to $q_{\text {ekol }}=0.85 ; g=2$ from $24 \mathrm{~m}$ with $Z P_{0}=0.88$ to $35 \mathrm{~m} \mathrm{ZP}=0.99$ at $q_{\text {ekol }}=0.45$ to $q_{\text {ekon }}=0.80 ; g=3$ from $20 \mathrm{~m}$ with $Z P_{0}=0.82$ to $30 \mathrm{~m} \mathrm{ZP} P_{0}=0.92$ at $q_{\text {ekol }}=0.4$ to $q_{\text {ekon }}=0.85$;

At the level of the hierarchy of their implementation culture - soil-soil reclamation difference the distances vary from $20 \mathrm{~m}$ for potatoes on peat soils to $38 \mathrm{~m}$ for cereals on sandy soils with a change of $q_{\text {ekol }}=0.4$ from $Z P_{0}=0.83$ to $q_{\text {ekon }}=0.85 ; Z P_{0}=1.08$.

The optimal design solution in the conditions for the whole system, depending on the share of different soil fertility and productivity of cultivated crops, is: $B_{0}=20 \mathrm{~m}$ at $q_{0}=0.6, Z P_{0}=0.583$.

Compliance with the condition of the environmental acceptability of the optimal design solution is determined by comparing the values $q_{s}=0.42$ and $\hat{q}_{\text {ecol }}=0.45$.

Since in this case $q_{s}<\hat{q}_{\text {ecol }}$, then the determined economically optimal design solution of the drainage parameters is environmentally acceptable in these conditions.

Comparative characteristics of the application of hydromechanical, empirical, economicmathematical (simplified optimization approach) and our improved optimization approach to substantiate the parameters of agricultural drainage at this object are given in [12].

\section{Conclusions}

Thus, we substantiated the parameters and constructions of agricultural drainage according to the method and obtained the results. The analysis of the results shows that the application of an optimization method, in contrast to traditional hydromechanical and empirical methods, makes it possible to assess the technological, economic and environmental efficiency of drainage under changing conditions. This increases the validity of design decisions in the construction and reconstruction of drainage systems.

\section{References}

[1] Шумаков Б.Б. Мелиорация в XXI веке (Melioration in the XXI century). Melioraciya i vodnoe xozyajstvo, 1996, No. 3, pp. 4-6. (In Russian).

[2] Kovalenko P., Rokochinskiy A., Jeznach J. etc. Evaluation of climate change in Polissia region and ways of adaptation to it. Journal of Water and Land Development, 2019, vol. 41, Issue 1, pp. 72-82.

[3] Рокочинський А.M. Наукові та практичні аспекти оптимізації водорегулювання осушуваних земель на еколого-економічних засадах: монографія (The scientific and practical aspects optimization of water regulation drained). Rivne, NUWEE, 2010, 351p. (In Ukrainian).

[4] Rokochinskiy A., Jeznach J., Volk P. etc. Reclamation projects development improvement technology considering optimization of drained lands water regulation based on BIM. Scientific Review Engineering and Environmental Sciences. 2019, 28 Issue 3(85), pp. 432-443.

[5] Шкинкис Ц.Н. Гидрологическое действие дренажа (Hydrological effect of drainage). Leningrad. Gidrometeoizdat, 1981, 311 p. (In Russian).

[6] Меліоративні системи та споруди (Reclamation systems and structures). State building codes of Ukraine V.2.4-1-99, 1999, 174 p. (In Ukrainian).

[7] Писарьков Х.А., Осушение сельскохозяйственных земель (Drainage of agricultural land). Leningrad, Selhozizdat, 1955, 251 p. (In Russian).

[8] Кубышкин В.П. Исследование параметров закрытого дренажу при осушении суглинистых почв различных генетических типов с учетом их водопроницаемости, характера водного питания и условий рельефа (Study of parameters of closed drainage during drainage of loamy soils of various genetic types, taking into account their water permeability, nature of water supply and relief conditions), Drainage of heavy soils. Moscow: Kolos, 1981, pp. 85-98. (In Russian). 
[9] Лазарчук Н.А., Муранов В.Г., Черенков А.В., Рокочинский А.Н. Технические указания по оптимизации параметров горизонтального дренажа на основании экономикоматематического расчёта при проектировании осушительных систем в Украинской ССР НТД 33-63-090-8 (Technical guidelines for optimizing horizontal drainage parameters based on economic and mathematical calculation in the design of drainage systems in the Ukrainian SSR NTD 33-63-090-8). Kiev: Ukrgiprovodhoz, 1989, 26 p. (In Russian).

[10] Фроленкова Н.А., Кожушко Л.Ф., Рокочинський А.М. Еколого-економічна оцінка в управлінні меліоративними проектами (Ecological and economic assessment in the management of reclamation projects). Rivne: NUWEE, 2007, 260 p. (In Ukrainian).

[11] Рокочинський А.М., Муранов В.Г., Тимейчук О.Ю., Волк П.П. та ін. Науково-методичні рекомендації до обгрунтування оптимальних параметрів сільськогосподарського дренажу на осушуваних землях за економічними та екологічними вимогами (Scientific and methodological recommendations for substantiation of optimal parameters of agricultural drainage on drained lands according to economic and environmental requirements). Rivne, 2013, 34 p. (In Ukrainian).

[12] Мажайский Ю.А., Рокочинский А.Н., Волчек А.А., Мешик О.П., Езнах Е. Природообустройство Полесья (Environmental management of Polesie). Ryazan: Meshcher.fVNIIIGiM them. A.N. Kostyakova, 2017, 902 p. (In Russian).

[13] Rokochinskiy A., Volk P., Pinchuk O., etc. Comparative evaluation of various approaches to the foundation of parameters of agricultural drainage. Journal of Water and Land Development, 2017, No. 34, pp. 215-220. 